\title{
MANIFESTO
}

\section{LETRA COMBATIVA: UM MANIFESTO CONTRA ESSA DÍVIDA PÚBLICA DO BRASIL}

\author{
Osmar Moreira dos Santos
}

Poucos falantes de língua portuguesa parecem estar interessados em descobrir o segredo da dívida trilionária do Brasil em relação aos seus credores, por outro lado há uma maioria levada a se interessar mais pelo segredo de uma trama de novela, das negociações envolvendo seu time de futebol, da vida do colega ou do vizinho e, principalmente, o das pegações entre atrizes e atores globais, expostas em revistas disponíveis em bancas ou caixas de supermercados.

Essa espécie de Central Invisível da Dívida, criada com a Independência do Brasil em 1822, e que acolheu, também como credores, os senhores de escravos remanescentes das Sesmarias, envolve não apenas o Banco Central, o Ministério da Fazenda, o Sistema Judiciário, o Sistema Midiático, as teorias, métodos, formas de interpretação e modos de funcionamento do sistema contábil, econômico e administrativo, público e privado, mas um departamento de inteligência para mapear e indicar formas de usurpação das riquezas materiais e simbólicas existentes no país ao mesmo tempo em que cria os dispositivos para essa cultura de massas e de entretenimento (a novela, o futebol, os brinquedos das crianças, as fofocas e modos de vida entre os ricos), capaz de desviar a atenção ou mesmo cortar a cabeça desses milhões de brasileiros, que, mesmo remanescentes da escravidão, suas condições de vida não justificam porque saíram dela.

Proposição 1: Parece que a quase totalidade dos falantes de língua portuguesa no Brasil, e do Brasil pelo mundo, substitui a busca e investigação sobre o segredo da dívida pública do Brasil, e que envolve a todos, pela busca do segredo encenado pela cultura da banalidade.

Proposição 2: A Central Invisível da Dívida, além de se naturalizar como se existisse desde a origem do universo, cria e falsifica uma forma de segredo para inviabilizar a sua descoberta por um povo, desviado em sua atenção ou destituído de suas cabeças.

Proposição 3: A recomposição do olhar ou da cabeça de um povo sem cabeça só é possível por uma política que parta desse corte, dessa cegueira ou 
cesura, e reinvente uma semiótica que coloque em pauta a Central Invisível da Dívida, seus agentes e seus mecanismos.

No meio do caminho, inviabilizando a cidadania de um povo, existe um segredo. E se a contabilidade pública falsifica, ou não torna disponível, a relação entre receita e despesa; o direito público e privado inviabiliza o acesso aos documentos para uma auditoria; e a economia liberal, em vez de explicar a trama, apenas inclui o trabalho e o trabalhador como mais uma mercadoria, só nos resta a língua e a literatura para interpelar esse segredo e sua semiologia.

A literatura dos países periféricos, atuando sob um crivo antropofágico, desde sempre, não reconhece esse débito em relação às chamadas literaturas do centro e o mundo que as produziu. Gregório de Matos, 100 depois da ocupação europeia do Novo Mundo, esconjurou essa "máquina mercante" no poema Triste Bahia; Sousândrade, 200 anos depois, anuncia a chegada de Wall Street, e o sacrifício de um povo, no poema O Guesa errante; Oswald de Andrade, no início do século XX, não vê a cidadania dos brasileiros, sem a devassa nos documentos históricos e coloniais, instalados no livro de poemas Pau Brasil, muito menos, a promessa de uma revolução periférica, sem as culturas indígena e africana propondo e orientando os roteiros.

Do ponto de vista da pesquisa e intervenção linguística, são inúmeros os trabalhos científicos que demonstram o sentido de os jesuítas, durante o período colonial, irem às tribos, aprenderem a língua dos índios, organizarem gramáticas e montarem um processo de imposição cultural que acaba por resultar em várias ordens de despejo, linguístico, cultural, territorial e ontológico de toda uma civilização, que hoje sabemos com mais de 40 mil anos de existência.

Se a literatura, até o golpe militar de 1964 no Brasil, se engajou, desde o século XVI, na construção de um dispositivo institucional e simbólico que dramatizasse e superasse a exploração do homem pelo homem, e, pós-1964, deixou um pouco de lado essa tradição para cotidianizar a política e politizar o cotidiano, a linguística, também, em seu engajamento, deixou um pouco de lado os estudos da língua como um sistema, para se preocupar com os textos, os enunciados e as enunciações dos sujeitos na cena discursiva e política.

Parece não ficar pedra sobre pedra, nessa intervenção linguísticoliterária, quando se nota o verso estilhaçado na poesia concreta, o poeta 
trocando um livro para comprar um baseado, as letras de hip hop encenando os tiroteios nas favelas, os professores afirmando em sala de aula a língua como se fala nos guetos e nas zonas rurais.

Essa interpelação dos professores, escritores e pesquisadores da linguagem ao sistema escravista ou neoliberal vai além do que esse sistema tem prescrito, ou seja, língua, literatura, filosofia, história, sociologia, antropologia, arqueologia, etc., são disciplinas inúteis, a menos que, no caso do ensino de línguas, prescreva-se a norma culta, combata-se a diversidade política e expressiva, e imponha aos falantes as normas daquilo que o sistema quer ouvir; e no caso da literatura, prescreva-se o elixir da autoajuda, para que os leitores-farrapos não arrebentem suas coleiras.

Mas a língua e a literatura insistem e levam o processo de distribuição da economia simbólica ao limite. Em Quarto de despejo, a escritora Maria Carolina de Jesus, em final dos anos de 1950 e início dos 60, divide o seu tempo em catar papel nas ruas de São de Paulo, ganhar alguns trocados para comprar algum alimento para si e seus filhos, além de escrever seu diário, dramatizando suas lutas cotidianas pela sobrevivência. Seu gesto de resistência, e cuidado de si, nas malhas desse saber e poder espúrios, encontra eco e interfaces com a vida de milhões de brasileiras e brasileiros, situados abaixo da linha da pobreza.

Quantos diários, entrevistas, documentos de memórias de tantas outras carolinas e severinos, poderiam compor uma rede de solidariedade, revolucionária, entre nós brasileiros?

Sim, a rede de escolas públicas de todo o Brasil poderia começar a pesquisar e estudar esses documentos de barbárie. Se, nos diários de Carolina de Jesus, temos um farol para se enxergar a potência subjetiva do povo pobre, é preciso colocar a escola como sistema diferencial de mediação, e organizar esse povo pobre numa luta coletiva por transformação e revolução social no Brasil.

Se dos papéis recolhidos do lixo, Carolina compra o macarrão do dia, e ainda os transforma numa problematização da vida de miséria na favela em que vive, os diários dessas carolinas, nas escolas, levariam os estudantes e professores a fazerem outros mapas: quais são as empresas estampadas nas caixas de papelão; quem são os exploradores, cujos nomes, recobrem as ruas das cidades; porque essa legião de miseráveis, padecendo ainda do mesmo regime de escravidão do século XVI ao século XIX no Brasil, são expelidos do 
conteúdo pedagógico das escolas; como acessar documentos públicos e institucionais sobre o pagamento de tributos e seu uso na criação e preservação da coisa pública; qual a origem das grandes fortunas locais e qual seria o impacto do rebatimento delas no financiamento da cultura popular e dos projetos sociais; como recuperar a força da civilização indígena e negra, instalando os seus signos em todas as escolas e centros de cultura dos bairros, país a fora?

Indiretamente, ou de forma tangencial, o campo linguísticoliterário, em parceria com as escolas, já tematiza a questão dos débitos e créditos linguísticos, literários e simbólicos, mas além de carecer de um foco sobre o sentido do segredo da dívida pública do Brasil em relação aos rentistas e à camada dos $10 \%$ mais ricos, é extremamente necessário inventar novas formas de dramatização desse problema, bem como inventar novas formas de se multiplicar a gestão dessa dramatização.

Maria Lúcia Fattorelli, coordenadora nacional da auditoria cidadã da dívida pública do Brasil, https://www.facebook.com/maria.fattorelli, tem mostrado através de sua obra crítica, e de sua atuação profissional, como funciona esse sistema centenário da dívida pública, fraudulento, perverso e criminoso, mas que funciona livremente, naturalmente, como se não existisse, ou seja, fora do radar da nossa melhor e mais radical crítica linguístico-literária e cultural.

Imaginemos, então, uma Maria Lúcia Fattorelli romancista, contista, dramaturga, historiadora, cineasta, rapper, cientista política, professora de língua portuguesa, de matemática, e o impacto desses novos sujeitos do discurso como um novo paradigma de interpretação e leitura do Brasil.

Na linha de Jessé de Souza, no livro $A$ elite do atraso, temos a colonização do olhar de todos os brasileiros por um paradigma que falsifica a imagem da elite brasileira, a seu ver sempre, em vez de moralista e legitimada para fazer a miséria que faz, um sujeito neoliberal, escravista, recalcado, e vira-lata; além desse paradigma nos considerar a todos (quase $80 \%$ da população), uma legião de imbecis, que é levada a acreditar que o problema crucial do Brasil é a corrupção do Estado, e não a do capital. Nesse sentido, e frontalmente contra esse paradigma de interpretação alienante, propõe que em vez de estudarmos o Brasil, apenas de um ponto de vista econômico, de 
direita ou de esquerda, faz-se, absolutamente necessário, disputarmos novos capitais, além do econômico, os capitais cultural e o das relações sociais.

Aos capitais cultural e o das relações sociais, propostos por Jessé de Souza, gostaria de acrescentar o capital político, pensado e posto em movimento pelos $80 \%$ mais pobres no Brasil. E começaria com uma provocação: se a maioria dos falantes de língua portuguesa, que até então tem sido levada a se interessar mais pelo segredo de uma cultura da banalidade, usasse seu "capital cultural" (o da banalidade) para a construção de uma performance como se fosse uma maria fattorelli romancista, contista, professora de língua portuguesa, que reviravolta política e simbólica poderemos esperar?

Imaginemos um romance que comece com a descrição da quebra de sigilo bancário, telefônico e fiscal dos donos da Rede Globo, envolvendo paraísos fiscais e personagens do sistema judicial e do departamento de estado e da justiça dos Estados Unidos. Como imaginar uma sequencia de tramas? Que personagens principais, secundários e de pano de fundo? Qual o melhor foco narrativo, na primeira pessoa, na terceira pessoa, numa pessoa difusa que se confunda com o próprio leitor? Que peças e quebra cabeças montar para que o leitor participe da construção do clímax? Qual o impacto desse romance, agora vendido em todas as bancas de revista e caixas de supermercados, para os antigos(as) leitores(as) da revista Caras e das outras sobre as novelas da Globo?

Ainda que revistas da cultura da banalidade criem uma zona de conforto para os seus infelizes leitores e leitoras, basta a formulação de um problema, bem fundado, e com uma efetiva promessa de aquisição de mais capital cultural (informação e contraponto para novas conversas), mais capital de relações sociais (ampliar os interlocutores de novas fofocas envolvendo a produtora das fofocas mal contadas - a Globo e suas revistas) e mais capital político (quebra de um dispositivo de poder simbólico de uma rede de televisão que, além de tudo, é uma concessão pública) para se ter uma verdadeira reviravolta no olhar, na sensibilidade, no desejo, e nos modos de se organizar para uma nova, e outra, prática política, envolvendo essa população de $80 \%$ de brasileiros.

A inteligência e racionalidade prática do povo pobre do Brasil é extraordinária não só porque se finge de morta para não ser dizimada, mas porque, paradoxalmente, pactua com essa natureza morta - que envolve a 
artimanha da cultura da barbárie - para se manter viva, e em movimento, e mais: apenas a espera de um problema bem formulado para se repactuar, não abertamente, com uma cultura da liberdade.

Prova disso, foi o modo como todos se engajaram na política cultural criada durantes os governos petistas, e para além do bolsa-família, do programa de apoio a agricultura familiar (Pronaf), entre outros. Em linhas gerais, a política cultural consistiu em: a) substituir o tal do "bom negócio" da cultura pelo estabelecimento da cultura como um "bem simbólico", em que o povo pobre pudesse afirmar a sua vida e expressar os seus talentos; b) promover o acesso aos bens universais (Kafka, Platão etc.,) à população de baixa renda, através de bibliotecas populares e comunitárias, bem como o acesso a modos de produção através de pontos de cultura por todo o país; c) fazer da cultura produzida, em todos os rincões do país, uma forma de geração de emprego e renda, bem como uma forma de emergência de novos mercados populares e de economia solidária.

Eis aqui o exemplo de como saltar de uma crítica radical do sistema da dívida, ainda que de forma indireta, e sem foco específico, empreendida, desde sempre, por atores importantes do campo linguístico-literário, para um novo ordenamento epistêmico, incluindo, nesse ordenamento, não só a crítica das representações, nesse caso, as representações engendradas, direta ou indiretamente, pelo que chamamos acima de Central Invisível da Dívida, mas, além dessa crítica das representações, a criação de novos dispositivos para a ampliação e gestão dessa crítica, até a derrubada do sistema como um todo.

Mas no meio do caminho, da autonomia e cidadania cultural do povo brasileiro, tem um golpe, um golpe jurídico-midiático, ameaçando-nos a todos com cenas ainda mais cruéis. E o povo precisa continuar acordado, não recuar muito, não voltar para a sua toca de sempre, ou seja, pactuar com a barbárie e se fingir de morto, e continuar sobrevivendo com sua existência feito natureza morta.

A personagem principal que controla os mecanismos da Central Invisível da Dívida Pública do Brasil, embora não apareça na cena dessa cultura da barbárie, pode ser imaginada com seus olhos vermelhos de ódio por essa civilização brasileira, forjada na escravidão, mas que quer ser uma civilização além de livre capaz de reinventar a humanidade. Sim, a civilização indígena nos legou uma sociedade contra o estado, mas que investe, antes, em sua ocupação, para fazê-lo perecer, a favor de uma miríade de associações de 
homens, mulheres e crianças livres; sim, a civilização afro-brasileira, nos legou uma filosofia musical e diaspórica, a favor da dança e incorporação dos deuses nessa miríade de associações de homens, mulheres e crianças livres; sim, uma civilização brasileira, com esses povos matriciais, dispondo, novamente, de suas terras que foram roubadas, e de uma política pública que estabeleça os parâmetros de uma reparação econômica envolvendo esses quase 400 anos de escravidão, poderiam, com esses recursos, não só propor um novo sistema de comunicação midiático, sem essa libidinagem comercial, e apostando numa economia da vida bela e sem acumulação de riquezas materiais, mas, mais do que isso: produzir condições efetivas para a vida, com suas tecnologias milenares, mesmo depois da invasão de misseis sobre o vale do silício.

Mas é hora de acordar, resistir e salvar o Brasil, antes que seja tarde demais e nos deparemos, apenas, com máquinas recolhendo corpos humanos, famintos e apenas sobrevivendo, como nos diários de Carolina, além de conduzidos aos lixões nas periferias das cidades fantasmas. A nova investida neoliberal não só quer revogar o sistema republicano, como um todo, e fazer devir a escravização do povo brasileiro, e da periferia do mundo, mas, num só golpe, e sem se dar conta (por seu irracionalismo extremo) estrangular-se a si mesma, nos arrastando a todos. Que vá sozinha e seja queimada por nosso fogo libertário. 